\title{
ETHNiC DifFERENCES In EdUCATIONAL Attainment AMONG the ChILdREN OF CANADIAN IMMIGRANTS ${ }^{1}$
}

\author{
Teresa Abada PhD \\ Feng Hou PhD \\ BALI RAM PHD
}

\begin{abstract}
Using the 2002 Ethnic Diversity Survey, this article examines the ethnic differences in university education attainment among the children of immigrants in Canada. We found that most groups achieve clear upward mobility across generations, while such upward pattern is not observed among Blacks and Filipinos. Asians (with the exception of Filipinos) attain higher academic achievements than most groups of European origins even when accounting for group variations in family background, and social and ethnic capital. Parental education was important in explaining the relatively low university completion rates among the second generation Portuguese and Italians. Rural residence of the father's generation was an important factor for the second generation Dutch and German youth, reflecting the different settlement patterns of these various groups. Our findings suggest that race/ethnicity has become a salient factor in educational stratification.
\end{abstract}

Keywords: ethnicity, mobility, education, second generation, immigrants

Résumé. À partir des données de l'Enquête sur la diversité ethnique de 2002, cet article examine les différences ethniques dans l'accession aux études universitaires des enfants des immigrants canadiens. Nous avons constaté que la plupart des groupes accède à une mobilité ascendante au fil des générations mais que le même parcours n'a pas été observé chez les Noirs et les Philippins. Les Asiatiques (sauf les Philippins) atteignent un rendement universitaire plus élevé que la plupart des groupes d'origine européenne même en tenant compte des variations en termes d'antécédents familiaux et capital social et ethnique. L'éducation des parents était importante pour expliquer les taux relativement faibles d'achèvement d'études universitaires chez les Portugais et les Italiens de

1. We are indebted to Alan Simmons, Sharon Lee, and René Morissette for important comments on an earlier version of this paper. We would also like to thank the editor and the anonymous reviewers for their insightful comments and suggestions.

(C) Canadian Journal of Sociology/Cahiers canadiens de sociologie 34(1) 2009 
deuxième génération. Une résidence en milieu rural pour la génération du père était un facteur important chez les jeunes hollandais et allemands de deuxième génération, reflétant ainsi les divers modèles d'établissement de ces groupes. Dans notre conclusion, nous disons que nos résultats indiquent que la race et les origines ethniques sont devenues un facteur fondamental dans la stratification de l'éducation.

Mots clés : ethnicité, race, mobilité, éducation, deuxième génération, immigrants

\section{INTRODUCTION}

Dhis article examines the ethnic differences in university education attainment in the children of immigrants, an increasingly diverse segment of Canada's population. The diversity is expanding due to large shifts over the last four decades in source countries from which immigrants originate. Shifts in the source countries were spawned by changes in immigration regulations in the 1960s that removed barriers to newcomers from non-European countries including Asia, Africa, Latin America, and the Caribbean. It is projected that, by 2017, visible minorities will constitute $20 \%$ of Canada's total population (Statistics Canada 2005). Determining the ethnic differences in educational attainment among the children of immigrants is vital for understanding why some groups achieve successful adaptation while others lag behind (Kao and Thompson 2003). The different pathways towards successful adaptation among the second generation have important implications for their relative position in the Canadian ethnic hierarchy and the different modes of reception encountered by these specific groups.

Research on ethnic differences in academic achievement has mostly originated in the United States (Portes and Rumbaut 2001; Zhou and Sao 2005; Portes et al. 2005). These studies show substantial differences in racial group achievement which consistently point to the success of some groups, for example the Chinese and Koreans (Zhou and Kim 2006), and the South Asians (Xie and Goyette 2003), while others exhibit signs of downward achievement, as for Blacks (Duncan 1994), Mexican Americans (Rumberger and Larson 1998), Laotians and Hmong (Miller 1995). The explanations for these group differences in the US include financial and human capital, family structure, community resources, cultural relations, as well as external factors such as racial stratification and economic opportunities (Zhou 1997).

A number of Canadian studies have provided valuable information on the educational attainment of the children of immigrants. Past studies demonstrate the success of the second generation, whose educational 
attainments and occupational status well exceed the achievement of the third generation (Boyd 2002; Boyd and Grieco 1998). Further evidence is noted in the very high educational aspirations among foreign-born youth (Anisef et al. 2000) and, in particular, among visible minorities, with the majority expecting to attain one or more degrees (Krahn and Taylor 2005). Using the 1991 census, Guppy and Davies (1998) provide a comprehensive analysis of ethnic groups with visible minorities demonstrating high school completion rates that exceed their invisible minority counterparts. Similarly, Dinovitzer et al. (2003) find that foreign-born youth for whom English is a second language have a greater propensity to attend university.

High levels of educational attainment, however, are not observed among all the children of immigrants; variations are observed by ethnicity and years since immigration. Recent arrival shows a disadvantage in school performance, particularly in reading test scores among the children of immigrant parents, in comparison to children of Canadianborn parents (Worswick 2004). However, the same study revealed that longer residence was associated with better school performance in this category, suggesting that those who arrive in early childhood have the same educational outcomes as those whose parents were born in Canada. The similar university educational attainments among those arriving early as immigrants and those born in Canada are also observed among Caribbean-born Blacks (Simmons and Plaza 1998). Children who arrive as immigrants in early childhood may therefore be considered to have higher acculturation rates and higher educational outcomes than those who arrive later (Kalbach and Kalbach 1995).

Segmented patterns in educational attainment are particularly salient not just by ethnicity but possibly at the university level. Studies that examined ethnic variations have shown that immigrant children from developing countries have lower university completion rates than those from developed countries (Halli and Vedanand 2007). A study by the Toronto Board of Education also shows a substantial portion of Caribbeanborn Black students enrolled in nonuniversity preparatory programs, including vocational and occupational programs, while Asian youth and African-born Blacks demonstrate higher enrollments in Advanced Placement programs (Yau et al. 1993). Further ethnic differences are observed in the academic achievement of refugee youth in Alberta, where only $38 \%$ of visible minorities were enrolled in university-stream classes in comparison to $67 \%$ of Yugoslavian youth (Wilkinson 2002). This suggests that lack of academic preparation for university in the early school years may manifest in lower levels of university completion rates, while some groups may be on their path to pursuing higher education. An im- 
portant question remains, therefore, to what extent are these ethnic variations observed in university educational attainments and what are the reasons are for these variations.

To date, the lack of available data has not allowed a systematic examination of the factors that create these segmented patterns in academic achievement. Past studies have focused mainly on one or two ethnic groups in ascertaining the factors influencing educational outcomes (see, for example, Li 2001; Wilkinson 2002; Smith et al. 2005; Codjoe 2001; Chow 2000). Our study extends the literature by providing a comprehensive analysis of group differences in university completion rates across a large range of visible minority and European groups, each possessing varying levels of human and social capital and their own unique settlement experiences with the host society.

Using large national representative survey data, we examine the extent of ethnic differences in university educational attainment and the salience of structural and cultural factors that explain some of these differences. Our study is unique in discerning the importance of parental human capital, social and ethnic capital, in accounting for these group differences in university completion rates.

\section{Theoretical Framework: Parental Human Capital, Social Capital and Modes of Incorporation}

Immigration scholars use the term "segmented assimilation" to describe the major differences in the integration process among the children of immigrants. The possible divergent pathways include: assimilation into mainstream society; economic success but with preservation of ethnic identities and the community's values; and downward mobility into the underclass or urban poverty (Portes et al. 2005; Portes and Zhou 1993). The underlying factors that determine the integration of an immigrant group to a particular segment of the host society include the strength of parental human and financial capital, and how these individual factors interact with structural factors. Success of one group may be attributed to the strength of the family and immigrant community resources while community disadvantages contribute to the downward mobility of some groups (Portes and MacLeod 1999).

Researchers working within the human capital framework assert that highly educated parents have the financial and nonmonetary resources to invest in their children's abilities early on, including access to information for opportunities and potential downsides to the surrounding environment (Portes et al. 2005; Corak 2001). Children with highly edu- 
cated parents benefit from access to good schools, safe neighbourhoods, and resources from formal and informal organizations (Zhou 1997:988). These advantages can accumulate over many years from early childhood through adolescence, producing the skills and expectations for university attendance (Heckman 2000). Studies in the US point to family SES as a major influence in explaining the difference in high school drop out rates and postsecondary achievement between Mexican Americans and Whites (Warren 1996); total number of years completed among the Filipinos and Cubans; and lower university enrollment among Blacks, Cambodians, and Mexicans (Rumbaut 2005).

The educational differentials across ethnic groups observed among the foreign-born population may affect the differences in the second generation's academic achievement. The highest attainments among the Chinese and the South Asians may demonstrate an advantage among the subsequent generation (Hou and Balakrishnan 1996). Likewise, the lower attainments of the parental generation particularly among the Portuguese, Italians, and Blacks may show lower educational outcomes among the second generation. Therefore, these national differences on educational attainment are largely attributable to differences in human capital endowments (Portes and MacLeod 1996).

Parental human capital, however, may not be enough to explain the resiliency of some ethnic effects, or why some groups show clear advantages despite coming from lower parental resources, suggesting that social capital in the family and the immigrant community also plays a salient role in accounting for these group differences. Coleman (1990) emphasizes the significance of closure in tightly knit ethnic communities, where parents get to know other parents and children and share similar values, obligations, and social supports. Such closure facilitates supervision which can be effective in discouraging delinquent behaviour and providing aspirations for young immigrants. As Zhou (1997) contends, the greater the involvement to one's community, and the tighter the ethnic community, the greater the conformity to the group's expectations, which in turn can help immigrants and their children overcome their structural disadvantages.

Intact families also provide a tighter monitoring of children's activities and strong family ties have been linked to academic achievement despite a disadvantaged SES parental background (Valenzuela and Dornbusch 1994). An analysis of school performance among Hong Kong immigrant students found that the presence of father in the household was an important factor in their academic achievement suggesting its relation to close parental guidance and supervision (Chow 2000:107). Immigration scholars also provide evidence that a bilingual background may pro- 
vide immigrant children the necessary resources to succeed in education as it provides them greater access to community networks (Glick and White 2003; Dinovitzer et al. 2003) and encourages effective communication with their parents (Mouw and Xie 1999).

The different modes of incorporation reflect the context into which immigrants are received. This is expected to have lasting effects on the integration of adults and their children (Zhou 1997). Determined by policies that grant resettlement assistance, public perception of immigrant nationalities, and intertwined with cultural aspirations, the settlement experiences of the parental and earlier generations contribute to the diversity of various communities (Portes and MacLeod 1996). These community differences condition the extent to which the advantages or disadvantages experienced by the parental generation are transmitted to the subsequent generation. Immigrants more favourably received by the host society, or those who do not encounter discrimination, are expected to experience a faster socioeconomic advancement and a smoother adaptation process, regardless of the human capital they possess (Portes and MacLeod 1999:257).

The earlier wave of European immigrants to Canada, who were admitted mainly on the basis of national origin, were largely rural and generally have lower levels of education than immigrants who came after 1970 and were largely urban. The experiences of Dutch immigrants reflect their rural settlements shortly after the Second World War, in which thousands were recruited for their agricultural skills. The Dutch farmlands in Ontario and the West became important centres of settlement (Troper 2000) which may have reduced the need to pursue education at the tertiary level. The lower academic achievement for European groups also occurred during the period of numerous blue-collar jobs that did not require postsecondary credentials (Davies and Guppy 1998). Moreover, the Portuguese and Italians, who are mainly involved in the fields of construction and manufacturing, are able to achieve economic stability despite their lower levels of education at the time of arrival, and, in fact, are noted for their high levels of home ownership (Teixeira 2007; Balakrishnan and $\mathrm{Wu}$ 1992). The groups who initially faced disadvantages in the labour market due to lower levels of education have improved their earnings and occupational status (Richmond 1990). Despite lower parental education the assimilation of these groups provides an opportunity for advancement among the subsequent generation.

The context that receives visible minorities plays an important role in their process of integration. The new waves of immigrants, faced with the points system admissions criteria, still encounter barriers regardless of higher levels of educational attainment. Studies show a significant dis- 
advantage in the labour market encountered by native- and foreign-born Black men (Hum and Simpson 2000). Also, the immigrant women admitted under the Domestic Worker and the Live-In Caregiver Programs (notably from the Caribbean and the Philippines) since the late 1970s face severe devaluation of foreign credentials, situating them near the bottom of the economic strata (Kelly 2006; Simmons 1998). The lower rate of return to schooling among the parental generation may hinder the progress of the children of immigrants. The disadvantages that visible minority parents must endure, condition their perception of what is attainable in the host society and hence the future achievements of their children (Zhou 1997).

Discrimination encountered during childhood also creates difficulties for the second generation as they navigate through the educational system. These collective experiences may facilitate a defeatist attitude, providing a reason to withdraw from academic activities (Ogbu 1991). On the other hand, discrimination can provide a motivation for youth to succeed in school, using education as a means to overcome systems of inequality and oppression (Sue and Okazaki 1990). Researchers have linked the marginal status of Asian Americans in areas such as politics, sports, and entertainment as blocked opportunities that provide a reason to avert their disadvantages, by pursuing careers (for example science and engineering) that are highly dependent on educational achievement (Xie and Goyette 2003; Sue and Okazaki, 1990). Hence, experiences of exclusion may very well have a positive effect on the pursuit of postsecondary education, particularly for visible minority youth.

Immigrants admitted as skilled immigrants, entrepreneurs, the selfemployed, and investors (specifically under the Business Immigrant Program) particularly those from Hong Kong, China, and India face circumstances that set them apart from those who arrive under the Live-in Caregiver program or those who face wage disadvantages in the labour market. Armed with occupational skills or ample financial resources, many of them are able to reach the middle and upper echelon of the economic stratum, despite challenges associated with social and cultural incorporation (Simmons 1998). These advantages, coupled with cultural orientations to succeed in the host society, contribute to the building of social networks and the emergence of ethnic communities characterized by solidarity among its members (Portes and MacLeod 1999). The growth of immigrant enterprises and ethnic businesses not only in Toronto and Vancouver but also in the smaller urban areas provide a site for the formation of social capital which Asians can turn to for support and social mobility (Li 2003). Hence, the children of these immigrants can benefit from the strength of these community resources and their family 
advantages, increasing their chances of educational success (Portes and MacLeod 1999). Immigrant children who are recipients of these different modes of incorporation either benefit from the community advantages or must contend with the disadvantages of their respective ethnic communities. We cannot directly test the proposition of these community differences on the basis of individual differences, because it entails an effect that applies to all members of the ethnic group (Zhou 1997, as cited in Portes and MacLeod 1996). Hence, we follow the proposition specified by Portes and MacLeod where we anticipate the ethnic effects will remain significant even after controlling for parental human capital and social capital factors.

We examine the extent to which parental human capital and social capital mitigate the ethnic differences in university educational attainment. We hypothesize that parental education will account for the educational differences among the children of immigrants. Ethnic groups who have the lowest attainments are anticipated to be the ones whose parents possess lower levels of education. However, parental human capital may not be enough to explain these differences, particularly the advantages observed among the Asian groups (Zhou and Kim 2006). We therefore turn to the roles of social capital in the family and immigrant community and the extent of influence they may have on the educational pathways of the second generation.

Children's educational attainment does not depend entirely on their own parents' human capital but also on the average skills in the previous generation of the ethnic group which are termed "ethnic capital" by Borjas (Borjas 1995). The main premise is that ethnicity acts as an externality in the human capital accumulation process. The average skill level of the ethnic group in the father's generation is critical in intergenerational mobility, and these differences in the levels of ethnic capital retard the convergence of the average skills of ethnic groups across generations (Borjas 1994; 1992). Lower skills are reflected in the decline in the earnings of Canadian immigrant groups (Aydemir and Skuterud 2005) as well as the earnings disadvantages particularly marked among Blacks, Indo-Pakistani, and Chinese (Stelcner 2000). Our study examines the impact of ethnic capital as measured by the average percentage finishing university degrees and mean earnings for the father's generation, i.e., male immigrants aged 35-50 by country of birth from the 1991 census.

We also examine the importance of rural residence in the father's generation. Rural and small town residence is associated with low levels of university completion due to difficulties of access to universities (Frenette 2004) and the lower demand for highly educated workers in rural areas (Bollman 1999). Some European origin groups (notably 
the Dutch and the Germans) are highly concentrated in rural and small towns; the difference in residential locations among parents' generation may affect group differences in educational attainment.

\section{Data ANd Methods}

This study is based on the 2002 Statistics Canada "Ethnic Diversity Survey" (EDS). The EDS is a national survey of over 42,000 non-Aboriginal Canadian residents aged 15 years or over. The survey was designed to provide information on how Canadians of different ethnic backgrounds interpret and report their ethnicity and how people's backgrounds affect their participation in the social, economic, and cultural life in Canada. For these purposes, the survey covers a wide range of topics including ethnic ancestry, ethnic identity, place of birth, visible minority status, religion, religious participation, knowledge of languages, family background, social networks, civic participation, interaction with society, attitudes, satisfaction with life, trust, and socioeconomic activities. The survey also oversamples visible/ethnic minority groups and thus obtains relatively large samples to allow comparisons between these minority groups and more established, large ethnic communities in various characteristics.

This study focuses on group differences in attaining university degrees among the second generation, including Canadian-born children of at least one immigrant parent and those who immigrated to Canada at age 12 or younger. Since young adults are more likely to finish university than older people and ethnic groups differ significantly in age structure, we limit our analysis to a subsample of about 3300 young adults aged 25-34. We do not include those for whom both parents were born in Canada (the third generation), since the third generation in our selected age range consists predominantly of British, French, and other European origin groups (over 99\%) and very few visible minority groups. Moreover, the difference in the percentage finishing university education between second and third generation European descendants is trivial and statistically insignificant when controlling for age, sex, and place of residence.

Within the selected sample, we identify the following 15 visible minority/ethnic groups each with a minimum sample size of about 50 persons. They include 7 visible minority groups: Chinese, South Asians, Filipinos, Arab/West Asians, other East Asians (Koreans and Japanese), and other visible minorities. ${ }^{2}$ There are also 8 ethnic groups with Euro-

2. Visible minorities are defined by Canada's Employment Equity Act as "persons, other than Aboriginal peoples, who are non-Caucasian in race or non-white in color." The regulations that accompany the Act identify the following visible minority groups: Chinese, South Asians, Blacks, Arab/West Asians, Filipinos, Southeast Asians, Latin Americans, Japanese, Koreans, and others (Renaud and Costa, 1999). 
pean background: British, French, German, Italian, Dutch, Polish, Portuguese, and other European groups. See Table 1 for sample size for each identified group.

Table 1. Percentage with University Degrees among Children of Immigrants* aged 25-34 by Racial/ethnic Groups

\begin{tabular}{|c|c|c|c|c|}
\hline & $\begin{array}{l}\% \text { with univer- } \\
\text { sity degree }\end{array}$ & $\begin{array}{l}\text { Lower } 95 \% \text { con- } \\
\text { fidence limits }\end{array}$ & $\begin{array}{l}\text { Upper } 95 \% \text { con- } \\
\text { fidence limits }\end{array}$ & $\begin{array}{l}\text { Sample } \\
\text { size }\end{array}$ \\
\hline Chinese & 59.4 & 53.0 & 65.7 & 231 \\
\hline South Asian & 56.9 & 50.4 & 63.4 & 226 \\
\hline Black & 24.9 & 19.2 & 30.6 & 227 \\
\hline Filipino & 37.5 & 27.3 & 47.8 & 89 \\
\hline West Asian & 51.9 & 37.2 & 66.5 & 48 \\
\hline Other East Asians & 68.6 & 56.0 & 81.1 & 56 \\
\hline Other visible minorities & 39.3 & 31.6 & 46.9 & 161 \\
\hline French & 47.5 & 39.5 & 55.5 & 152 \\
\hline German & 23.5 & 17.4 & 29.7 & 186 \\
\hline Italian & 31.1 & 25.7 & 36.5 & 287 \\
\hline Dutch & 20.9 & 13.9 & 28.0 & 131 \\
\hline Polish & 40.9 & 26.6 & 55.2 & 49 \\
\hline Portuguese & 22.6 & 13.2 & 32.0 & 80 \\
\hline Other European origins & 36.0 & 31.8 & 40.1 & 518 \\
\hline British & 37.6 & 34.5 & 40.8 & 889 \\
\hline All groups & 37.6 & 35.9 & 39.2 & 3330 \\
\hline
\end{tabular}

In our regression analyses, we include six sets of explanatory variables. The first set is basic demographic variables, including age (ranging from 25-34), sex (female=1), family structure, place of residence, and generation status. Family structure has four categories: lived mainly with biological parents until age 15 , lived mainly with birth mother until age 15 , lived mainly with birth father until age 15 , and lived with neither birth mother nor father until age 15 . The place of residence is coded as three categories: large metropolitan areas (the largest 8 metropolitan areas in Canada), small metropolitan areas (the other 18 metropolitan areas with a population of at least 100,000), and nonmetropolitan areas. Generation status is coded as four categories: generation 1.5 (those whose age at immigration was 6-12), generation 1.75 (those who immigrated before age 6), the second generation (born in Canada with both parents who were immigrants), the 2.5 generation (born in Canada, but with only one immigrant parent).

The second set of variables measures father's and mother's education. For each parent, parental education is coded as four categories: with 
university degree, some postsecondary education, high school graduation, less than high school graduation.

The third set of variables, coded as three categories, captures the individuals' mother tongue and family language environmen: (1) mother tongue is either English or French; (2) mother tongue is neither English nor French, but spoke English or French with parents until age 15; (3) mother tongue is neither English nor French, and did not speak English or French with parents by age 15 .

The fourth set of variables reflects individuals' ethnic networks and their sense of belonging or exclusion while growing up in Canada. One is whether the respondents reported that at least half of their friends were from the same ethnic group by age 15 . The second variable is whether the respondents ever felt uncomfortable or out of place because of their ethnicity, culture, race, skin color, language, accent, or religion by age 15. The third variable is whether the respondents reported a strong sense of belonging to their ethnic or cultural group.

The fifth set of variables captures what Borjas $(1992 ; 1995)$ refers to as "ethnic capital," measured by the average socioeconomic resources among respondents' parents' generation. Following Borjas' approach, we derive the average percentage finishing university degrees and mean earnings for male immigrants aged $35-50$ by country of birth from the 1991 census. Then we merge these two variables with our EDS data by respondents' father's (or mother's if the father was not an immigrant) country of birth. In our EDS sample, we can identify 76 countries (or regions) of birth based on parents' information. We use this same 76 country grouping in deriving variables from the 1991 census and in matching the two data sources.

The final set of variables is the percentage living in rural or small town (population less than 5,000) among respondents' father's generation. We follow the same approach used in deriving the above two ethnic capital variables.

We construct both logistic and Ordinary Least Squares regression models to examine to what extent the above six sets of variables can account for the observed differences in university completion rates among ethnic groups. Logistic regression is statistically more appropriate for the dichotomous outcome of whether someone finished university. However, the logistic and OLS models yield essentially identical results in the sign and significance of explanatory variables and the estimated university completion rates by visible minority/ethnic group. We only present OLS results since the interpretation of OLS model coefficients is straightforward. More importantly, with OLS results, it is easy to isolate 
the respective contribution of various explanatory variables to each visible minority/ethnic group's advantage or disadvantage in the outcome. ${ }^{3}$ The results of logistic models are available upon request.

The EDS is a probabilistic survey and a survey weight is assigned to each respondent to represent the target population at the national level. In our regression models, we standardize this survey weight by dividing it with the average weight in our study sample. This standardized weight has the advantage of maintaining the same distributions as those of nonstandardized weights, but avoiding an overestimation of the critical level (Statistics Canada 2003).

\section{Results}

\section{Group Differences in University Completion}

We observe wide differences in university completion rates between ethnic groups with the most educated group (the other East Asians, $69 \%$ ) exceeding well over three times the rate of those near the bottom of the hierarchy (the Dutch, 21\%). Visible minority youth in general outperform their White counterparts. A striking pattern is noted among the Asians, with the most highly educated groups by far being the other East Asians (Koreans and Japanese), followed by the Chinese (59\%), the South Asians (57\%) and the West Asians (52\%). Not all visible minority youth show an advantage in university completion. Only $25 \%$ of Blacks and $38 \%$ of Filipinos have attained a university degree.

For European groups, the highest levels of university completion are observed among the French (48\%), the Poles (41\%), with over one-third observed among the British, "other European groups," and the Italians. Less than one-quarter of Dutch, Portuguese, and German youth attained a university degree. ${ }^{4}$

\section{Group Differences in Family Background and Individual Characteristics}

Tables 2 and 3 focus on the ethnic differences in the family background and individual characteristics, key factors expected to shape the educa-

3. This is done following one variation of the Oaxaca decomposition method (Oaxaca and Ransom 1994). In this approach, the advantage/disadvantage of a group over the overall average in the outcome can be decomposed as the sum of the differences between variable means of the group and the variable means of all groups, with the differences weighted by the model coefficients of the pooled sample.

4. We produced the same table using the 2001 census data which are based on a much larger sample and thus more reliable (available upon request). The census results confirm the general pattern observed in the EDS for these group differences. Since census data do not contain information on most of our explanatory variables that are available in the EDS, the following section analysis is only based on the EDS. 
Table 2. Group Differences in Family Background and Individual Characteristics

\begin{tabular}{|c|c|c|c|c|c|c|c|}
\hline & 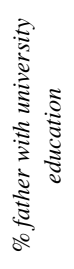 & 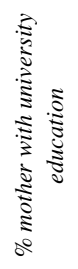 & 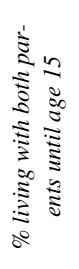 & 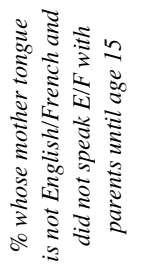 & 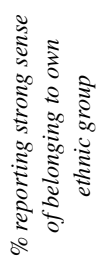 & 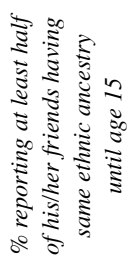 & 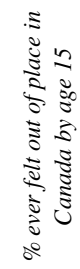 \\
\hline Chinese & 28.9 & 16.9 & 97.0 & 57.9 & 50.8 & 49.9 & 67.5 \\
\hline South Asian & 36.2 & 22.4 & 92.9 & 39.2 & 59.5 & 38.3 & 77.0 \\
\hline Black & 24.4 & 16.9 & 62.9 & 0.1 & 71.8 & 33.5 & 79.7 \\
\hline Filipino & 38.2 & 33.3 & 84.6 & 32.7 & 61.9 & 50.0 & 58.4 \\
\hline Arab/West Asian & 17.4 & 15.7 & 90.7 & 70.5 & 33.3 & 42.1 & 73.7 \\
\hline Other East Asian & 38.9 & 19.47 & 94.1 & 49.7 & 53.1 & 27.5 & 93.5 \\
\hline Other visible minorities & 25.8 & 17.5 & 87.5 & 56.9 & 45.5 & 35.8 & 61.9 \\
\hline French & 35.0 & 35.5 & 81.5 & 7.3 & 31.0 & 35.4 & 22.9 \\
\hline German & 16.5 & 12.4 & 87.9 & 13.5 & 39.9 & 19.1 & 28.5 \\
\hline Italian & 4.9 & 4.2 & 94.5 & 50.3 & 63.1 & 69.6 & 27.6 \\
\hline Dutch & 18.7 & 9.7 & 88.2 & 8.2 & 37.0 & 35.1 & 26.1 \\
\hline Polish & 21.1 & 22.4 & 81.7 & 46.2 & 57.0 & 30.0 & 46.9 \\
\hline Portuguese & 0.0 & 1.6 & 92.8 & 74.8 & 60.2 & 57.2 & 40.8 \\
\hline Other European origins & 21.4 & 15.5 & 87.4 & 37.4 & 48.9 & 29.7 & 33.8 \\
\hline British & 32.3 & 21.7 & 80.4 & 0.0 & 36.1 & 18.7 & 20.4 \\
\hline All groups & 24.0 & 16.9 & 86.0 & 27.5 & 47.9 & 34.8 & 38.7 \\
\hline
\end{tabular}

Source: 2002 Ethnic Diversity Survey

tional attainments of the children of immigrants. The table shows large group differences in parental education. The most educated fathers are the Filipinos (38\%), Other East Asians (Koreans and Japanese, 39\%), South Asians (36\%), and the French (35\%) with over one-third having attained a university degree. The proportions of mothers who attained a university degree are highest among the Filipinos and the French with over one-third, followed by the South Asians, Polish, and the British with just less than a quarter having attained a university degree.

The comparison of parental education and children's university attainment reveals large group differences in intergenerational mobility (see Chart 1). Most groups attain a higher percentage of university education than their parents but few show signs of stagnation. Italian and Portuguese children surpassed their fathers' educational levels by a substantial margin: $31 \%$ of Italian youth (compared to $4.9 \%$ of their fathers) 
Table 3. Father's Generation Characteristics among Children of Immigrants aged 25-34 by Racial/ethnic Groups

$\begin{array}{lccc} & \begin{array}{c}\text { \% father's gener- } \\ \text { ation with univer- } \\ \text { sity education }\end{array} & \begin{array}{c}\text { Log average an- } \\ \text { nual earnings of } \\ \text { father's }\end{array} & \begin{array}{c}\text { \% liveneration in rural } \\ \text { areas and small towns } \\ \text { among father's gen- }\end{array} \\ \text { Chinese } & 28.7 & 10.45 & 4.6 \\ \text { South Asian } & 32.6 & 10.53 & 6.7 \\ \text { Black } & 17.6 & 10.41 & 6.0 \\ \text { Filipino } & 41.6 & 10.39 & 5.0 \\ \text { West Asian } & 35.0 & 10.50 & 3.9 \\ \text { Other East Asians } & 41.5 & 10.44 & 7.2 \\ \text { Other visible minorities } & 20.0 & 10.34 & 5.2 \\ \text { French } & 29.5 & 10.62 & 18.2 \\ \text { German } & 22.2 & 10.65 & 24.4 \\ \text { Italian } & 10.6 & 10.59 & 8.6 \\ \text { Dutch } & 17.2 & 10.68 & 38.2 \\ \text { Polish } & 29.2 & 10.51 & 9.7 \\ \text { Portuguese } & 2.9 & 10.40 & 7.2 \\ \text { Other European origins } & 21.3 & 10.57 & 13.4 \\ \text { British } & 25.1 & 10.76 & 20.1\end{array}$

Source: 1991 census

Note: the three variables are derived from male immigrants aged 35-50 by country of birth in the 1991 census and then merged with the 2002 ethnic Diversity Survey by country of birth of respondents' parents.

\section{Chart 1. Comparing Children's and Fathers' Educational Attainment}

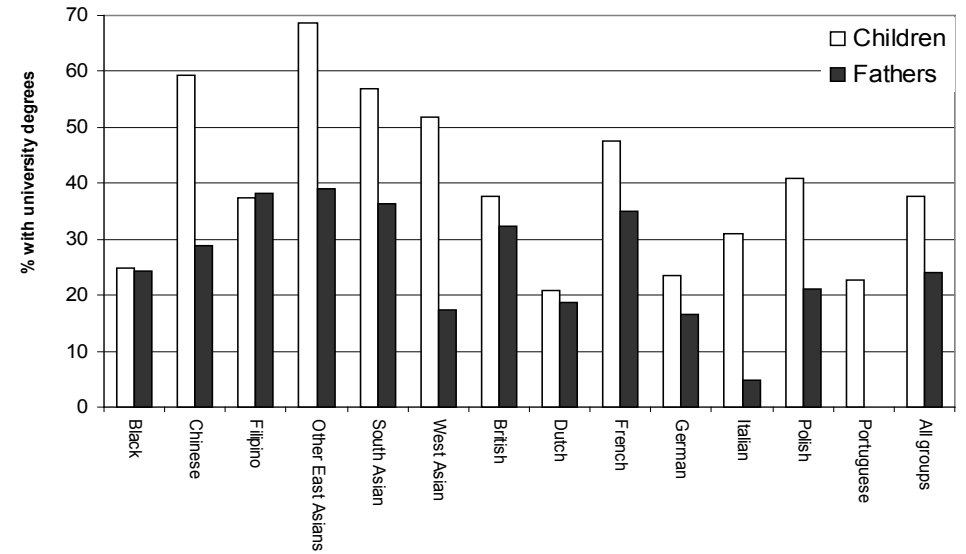

and $23 \%$ of Portuguese immigrants (compared to $0.0 \%$ of their fathers) attained a university degree. The intergenerational mobility among Chinese and Polish youth is also notable with twice as many youth completing a university education relative to their father's attainment. This upward pattern is not observed for the Filipinos and Blacks which are also 
the only groups that youth on average do not attain a higher proportion of university degrees than their fathers.

The highest proportions (over 90\%) who lived in intact families are the Chinese, the South Asians, other East Asians, and the Southern European groups. Overall, Blacks were more likely to grow up in singleparent households (37\%) than any of the other ethnic groups. There are also large group differences in social networks and social capital in the immigrant community. The highest proportions who reported a strong sense of attachment to their ethnic group are the Blacks (72\%), the Filipinos (62\%), the South Asians (60\%), the Italians (63\%), and Portuguese $(60 \%)$. A majority of visible minority youth (over $50 \%$ ) well exceeds their non-visible minority counterparts of reporting ever feeling out of place by age 15 due to their ethnicity, culture, race, skin color, language, accent, or religion.

Table 3 demonstrates considerable group differences in ethnic capital with Filipinos and other East Asians having the highest percentage finishing university education among the father's generation (around 42\%), while Portuguese $(3 \%)$ and Italians $(11 \%)$ have the lowest levels. The father's generation among most ethnic groups predominantly resided in the urban areas but one third of the Dutch and a quarter of German father's generation lived in rural areas.

\section{Multivariate Analysis}

\section{The effects of explanatory variables}

To show how our six sets of explanatory variables affect group differences in university completion rates, we construct a multivariate regression model in Table 4. The regression coefficients show that women tend to have higher university completion rates than men. This finding is consistent with the general observation that young females have outnumbered males in postsecondary enrolments and completion (Shaienks and Gluszynksi 2007). Older age is associated with lower university completion rates. Youth who did not live with both parents or lived with a lone mother by age 15 have lower university completion rates than those who mainly lived with two biological parents. Youth who live in large and small metropolitan areas have higher university completion rates than those who live in rural areas or small towns.

Child immigrants whose age at immigration was between 6 and 12 (generation 1.5) are less like to finish university degrees than Canadianborn children with one Canadian-born parent and one immigrant parent. Child immigrants whose age at immigration was younger than 6 (generation 1.75) are similar to Canadian-born children with two immigrant 
Table 4. Ordinary Least Squares Models Predicting Finishing University Degrees

Intercept

B Standard error

Chinese

$-1.471 * * *$

0.627

South Asian

$0.160 * * *$

0.035

Black

$0.106 * *$

0.033

Filipino

$-0.161 * * *$

0.036

West Asian

$-0.106^{*}$

0.052

Other East Asian

$0.129 *$

0.059

Other visible minorities

$0.176^{* *}$

0.062

French

$-0.007$

0.038

German

$0.097 * *$

0.035

Italian

Dutch

$-0.050$

0.029

$-0.006$

0.026

Polish

Portuguese

$-0.001$

0.039

0.030

0.046

Other European origins

$-0.013$

0.040

Age

Female

Not live with parents

0.016

0.021

$0.005 *$

0.002

$0.064 * * *$

0.012

$-0.283 * * *$

0.074

Lone mother

Lone father

$-0.117 * * *$

0.019

0.004

0.036

$0.130 * * *$

0.017

Small urban

$0.049 *$

0.022

Generation 1.5

$-0.107 * * *$

0.025

Generation 1.75

$-0.041 *$

0.020

Generation 2

Mother university

$-0.048 * *$

0.016

$0.099 * * * \quad 0.022$

Mother some postsecondary

$0.068 * * * \quad 0.018$

Mother high school graduation

$0.061 * * * \quad 0.017$

Father university

$0.307 * * * \quad 0.019$

Father some postsecondary

$0.121 * * *$

0.018

Father high school graduation

$0.053 * *$

0.018

$-0.010$

0.018

$\mathrm{E} / \mathrm{F}$ is mother tongue

0.016

0.026

$\mathrm{E} / \mathrm{F}$ not mother tongue, speaking $\mathrm{E} / \mathrm{F}$ with parents

0.000

0.012

Mostly ethnic friends

$0.049 * * * \quad 0.013$

Felt out of place

$0.066^{* * *} \quad 0.013$

Father generation education

0.089

0.073

Father generation earnings

0.139

0.077

$\%$ living in rural and small towns

$-0.483 * * *$

0.130

Sample size

3330

Adjusted $\mathrm{R}^{2}$

0.151

Source: 2002 Ethnic Diversity Survey

Significance: $* * * \mathrm{p}<.001,{ }^{*} \mathrm{p}<.01,{ }^{*} \mathrm{p}<.05$ 
parents (generation 2) in the outcome, but both groups are less likely to finish university degrees than those who have one Canadian-born and one immigrant parent (generation 2.5). Both mother's and father's educational levels significantly predict youth's university completion rates, although the effect of father's education is stronger than mother's education. Youth whose father had a university degree had a university completion rate 31 percentage points higher than youth whose father did not finish high school. In comparison, youth whose mother had a university degree had a university completion rate about 10 percentage points higher than youth whose father did not finish high school.

The effects of mother tongue and family language environment are not statistically significant. This is understandable since children of immigrants in our study sample finished all their formal education within the Canadian educational system and should not have difficulties with the host-country language. It should be noted that many immigrants who came to Canada after the 1980s spoke neither English nor French. Although the language difficulty may affect these immigrants' economic performance, non-English/French family environment had no direct impact on their children's university education attainment.

Growing up with most (at least half) friends of the same ethnic ancestry benefits the second generation in their educational attainment. Feeling a sense of exclusion during childhood was positively associated with university attainment. This is consistent with the proposition that marginal status may heighten minority youth's achievement orientations. The average earnings of father's generation are positively associated with university completion (significant at $\mathrm{p}<.10$ ), while the percent living in rural area and small towns among the father's generation are negatively associated with university completion.

\section{Adjusted group differences in university completion}

When group differences in demographic factors, parental education, social and ethnic capitals are accounted for, there are relatively few variations among European groups in university completion rates, with only the French having significantly higher rates than the British (Table 4). The observed disadvantages among the Dutch, Portuguese, and German largely disappear (comparing Table 1 and Table 4). In comparison, the variations remain relatively large among visible minorities. While other East Asians (Koreans and Japanese), Chinese, South Asians, and West Asians maintain their significant advantages in university completion rates over the British when the selected sociodemographic and family background variables are accounted for, Blacks and Filipinos show significant disadvantages relative to the British. 
Since the regression model in Table 4 does not directly show the extent to which the selected six sets of explanatory variables account for group difference in university completion rates and the relative contribution of each set of explanatory variables, we perform the Oaxaca decomposition and summarize the results in Table 5. The first column in Table 5 presents the observed university completion rates as in Table 1. The second column presents university completion rates estimated for the OLS model in Table 4, by assuming each group has the same characteristics as the whole sample in the control variables included in the model. For instance, on average, 59.4\% of Chinese youth finished university completions (Column 1). Based on the regression model in Table 4 and if the Chinese had similar characteristics in the six sets of explanatory variables as the total sample, the estimated university completion rate for Chinese youth would be $52.4 \%$ (see Column 2). Column 3 is the difference between the observed (column 1) and estimated university completion rates (column 2) for each group. This difference shows the portion of a group's advantage or disadvantage that can be "explained" by the control variables (from columns 4 through 9). Again, using the Chinese

Table 5. Observed and Estimated Percentages with University Degrees by Racial/ethnic Group

\begin{tabular}{|c|c|c|c|c|c|c|c|c|c|}
\hline & 1 & 2 & 3 & 4 & 5 & 6 & 7 & 8 & 9 \\
\hline & \multicolumn{9}{|c|}{$\begin{array}{c}\text { Contributions to the "explained" percent- } \\
\text { age points }\end{array}$} \\
\hline & 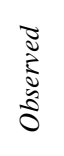 & 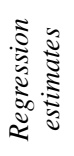 & 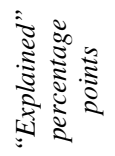 & 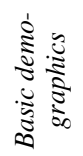 & 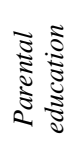 & $\begin{array}{l}0 \\
\infty \\
5 \\
5 \\
5 \\
3\end{array}$ & 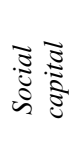 & 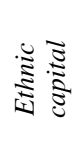 & 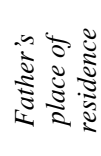 \\
\hline Chinese & 59.4 & 52.4 & 7.0 & 1.3 & -0.7 & 0.6 & 2.6 & -1.4 & 4.6 \\
\hline South Asian & 56.9 & 46.9 & 9.9 & -0.1 & 3.3 & 0.5 & 2.7 & 0.0 & 3.6 \\
\hline Black & 24.9 & 20.3 & 4.6 & -0.3 & 1.7 & -0.3 & 2.7 & -3.0 & 3.9 \\
\hline Filipino & 37.5 & 25.7 & 11.8 & -0.1 & 6.4 & 0.2 & 2.1 & -1.1 & 4.3 \\
\hline West Asian & 51.9 & 49.3 & 2.5 & -3.4 & -2.7 & 0.4 & 2.7 & 0.6 & 4.9 \\
\hline Other East Asians & 68.6 & 54.0 & 14.6 & 2.6 & 5.5 & 0.4 & 3.3 & -0.5 & 3.3 \\
\hline Other racial minorities & 39.3 & 35.6 & 3.6 & -0.5 & 1.9 & 0.2 & 1.6 & -3.8 & 4.2 \\
\hline French & 47.5 & 46.1 & 1.4 & -1.0 & 4.8 & -0.3 & -1.0 & 1.0 & -2.0 \\
\hline German & 23.5 & 31.4 & -7.8 & -0.5 & -1.5 & -0.1 & -1.5 & 0.8 & -5.0 \\
\hline Italian & 31.1 & 35.7 & -4.6 & 2.1 & -9.5 & 0.3 & 1.0 & -1.2 & 2.6 \\
\hline Dutch & 20.9 & 36.3 & -15.3 & -1.2 & -2.1 & -0.3 & -0.8 & 0.7 & -11.7 \\
\hline Polish & 40.9 & 39.4 & 1.5 & -2.3 & 1.7 & 0.3 & 0.3 & -0.6 & 2.1 \\
\hline Portuguese & 22.6 & 35.1 & -12.5 & -0.3 & -12.8 & 0.4 & 1.2 & -4.4 & 3.3 \\
\hline Other European origins & 36.0 & 37.9 & -2.0 & -0.1 & -1.3 & 0.1 & -0.6 & -0.5 & 0.3 \\
\hline British & 37.6 & 36.4 & 1.3 & -0.3 & 4.5 & -0.4 & -2.0 & 2.5 & -3.0 \\
\hline
\end{tabular}


as an example, the number in column 3 suggests that about 7 percentage points of Chinese youth's university completion rates can be accounted for by their differences from the total sample in the six sets of control variables. To pinpoint the role played by each set of control variables, Columns 4 to 9 show the contribution from each set of control variables to the "explained" portion. The contribution of each set of control variables is calculated as the sum of the differences between variable means of a specific group and the variable means of all groups, weighted by the model coefficients of the pooled sample (also see footnote 2). Therefore, for each group, the sum of column 4 to column 9 equals the number in column 3. In the case of Chinese youth, their advantage in father's generation place of residence (4.6 percentage points), social capital (2.6), and basic demographics (1.3) was partially offset by their disadvantage in ethnic capital (-1.4 percentage points) and parental education (-0.7).

Comparing Column 3 and Column 1 shows that differences in demographic factors, parental education, social and ethnic capitals account for part of the advantages in university completion rates among some Asian groups. With the average characteristics as the whole sample, the university completion rates would reduce by 14.6 percentage points for other East Asians, 9.9 percentage points for South Asians, and 7 percentage points for the Chinese. The university completion rates would also reduce by 11.8 percentage points for Filipinos and 4.6 for Blacks. The results in Columns 4 to 9 suggest that visible minorities generally benefit from the fact that their father's generation tends to be more concentrated in metropolitan areas than European groups. Social capital (i.e., strong sense of belonging to own ethnic group, larger ethnic friends network) and sense of isolation tends to increase visible minority groups' university completion rates. Ethnic capital (due primarily to low average earnings among father's generation) tends to reduce visible minorities' university completion rates. High levels of parental education contribute largely to youth university completion rates among Filipinos, other East Asians, and South Asians.

Group differences in demographic factors, parental education, social and ethnic capitals also account for a large part of the disadvantages in university completion rates among some European groups. With the average characteristics as the whole sample, the university completion rates would increase for the following ethnic groups: 15.3 percentage points for Dutch, 12.5 percentage points for Portuguese, 7.8 percentage points for German, and 4.6 percentage points for Italians. High concentration in rural areas and small towns among the father's generation is the most important factor contributing to the relatively low university completion rates among Dutch and German youth. Low levels of parental education 
are the most important variables contributing to the relatively low university completion rates among Portuguese and Italians.

\section{Discussion and Conclusion}

This paper shows very large group differences in university education attainments among the children of immigrants. Asians and the French show higher levels of educational attainment than the British, while the Filipinos and especially the Blacks lag behind other groups. Most groups achieve upward mobility across generations in the sense that the second generation has achieved much higher educational levels than their fathers while Blacks and Filipinos are the only groups that do not exceed their fathers' levels of education.

Our findings show that parental education, in particular father's attainment of a university degree, is a strong predictor of university completion among the children of immigrants. This is consistent with Kao and Thomson (2003)'s proposition that children whose parents have high levels of education also have a greater propensity to attain a university degree. Indeed, highly educated parents have the financial and nonmonetary resources to invest in their children's abilities early on that place them on track for the pursuit of higher education (Corak 2001). As expected, family structure was found to be associated with higher levels of educational attainment. As observed in past literature, growing up in a two-parent household can provide a tighter monitoring of children's activities, which can carve the path for achieving academic success (Valenzuela and Dornbusch 1994). The rural place of residence among the father's generation was found to be associated with lower likelihood of obtaining a university degree. This underscores the importance of understanding the settlement patterns of the parental generation groups and how the advantages and disadvantages encountered by specific immigrant nationalities impact on the educational pathways of the subsequent generation.

What is striking is that while parental education could not account entirely for group differences in educational attainment, similar studies in the US also point to the persistence of the ethnic effect (Hirschman 2001; Portes and MacLeod 1999). This underlines the need to go beyond human capital factors and look for social and cultural factors as possible explanations. In this study, we found that social capital was more salient for the educational advantages observed among visible minorities than among European groups, although ethnic capital also played a role for some groups. We found that having grown up with friends of the same 
ethnic background was positively related to university completion. This reflects the parents' ethnic networks which may be beneficial in providing forms of institutional and informal supports that facilitate the pursuit of a university education. In studying the high academic achievements among Korean and Chinese second generation, Zhou and Kim (2006) explain the importance of ethnic networks for the provision of academic enrichment, teaching of family values, and a place where coethnic ties are rebuilt and where immigrants with varying levels of socioeconomic background come together.

Our study also found that feelings of exclusion during childhood because of one's race or ethnicity were associated with the attainment of university education, suggesting that anticipated disadvantages can be an important motivator to succeed academically. A study of parental expectations among Chinese Canadian immigrant parents (Li 2001) found that perceived racism and limited occupational opportunities were reasons that parents held specific career aspirations for their children. Engendered by an awareness of one's visible minority status and anticipated blocked opportunities, the drive to succeed academically becomes an avenue to challenge race-based inequality in the host society and the Canadian labour market in particular (Li 2001:490; Sue and Okazaki 1990).

The fact that human and social capital factors could not account for the advantages of Asian groups suggests examining cultural explanations. A greater sense of obligation to one's parents provides a reason to do well academically (Fuligni et al. 1999), while an orientation that favours self-reliance and achievement has an impact on academic success (Caplan et al. 1991). These possible explanations could not be examined in this study due to data limitations but they warrant further attention, specifically for groups that exhibit higher educational outcomes. The modes of incorporation which determine the context of arrival among these minority groups cannot be ignored. The advantage of arriving with high levels of human capital coupled with the ability to rely on the strength of their ethnic community resources can further contribute to the successful pursuit of higher education among the children of immigrants.

The Filipino immigrant youth exhibit an educational disadvantage in Canada. The paradox is that the parents of these youth are among the most educated of all immigrant parents yet the children do not exceed their parents' educational levels as other Asian youth do. According to Kelly (2006:24), Filipinos have the most segmented patterns of occupation in Canada and are heavily concentrated in clerical work, health care, hospitality, retail, and manufacturing. This underscores the importance of discerning the devaluation of the parental generation's educational 
credentials earned outside of Canada and how this disadvantage is reproduced in the subsequent generation (Li 2003).

Our study shows that Blacks remain at the bottom in university completion rates among large visible minority/ethnic groups when group differences in sociodemographic factors are taken into account. The earnings penalties of Blacks may reduce Black youth's motivation to pursue higher education. Immigrant groups, especially native and foreign-born black men still encounter wage disadvantages in the labour market (Hum and Simpson 2000). Also, women who arrived under the Domestic and Live-In Caregiver Program especially from the Caribbean and the Philippines face devaluation of their foreign credentials (Simmons 1998). These disadvantages may in turn be transmitted to the next generation. According to Simmons and Plaza (1998), the lower rates of return to education for Black men might discourage them from pursuing further education. Black youth's disadvantage also requires further scrutiny of the obstacles that this group may encounter in the earlier stages of schooling and its accumulation throughout their high school years. Past studies also point to a greater proportion of these students enrolled in nonacademic tracks (Yau et al. 1993). These racial differences in relation to course enrollments will have implications for the segmented patterns in educational attainment among the second generation and the factors underlying these differential placements are important considerations for future research.

Among European ethnic groups, differences in university education attainment are relatively small when group differences in family background are accounted for. Parental education was important in explaining the relatively low university completion rates among the Portuguese and the Italians. This is not surprising as these groups tend to be more concentrated in manual jobs with a much lower proportion, especially among Portuguese immigrants, in management and professional positions (Ornstein 2000). Hence, the lower likelihood of youth attaining higher education may be reflected in the lower proportion of the parental generation in professional occupations (Rice 1999).

The rural residence of the father's generation was the most important variable explaining the Dutch effect and, to some extent, the German effect (though not in its entirety), reflecting the settlement experiences of these groups. The previous generations were recruited for their agricultural skills and established farmlands which became important centres of settlement shortly after the Second World War (Troper 2000). Hence, the subsequent generations would have benefited from these viable agricultural enterprises, probably with a lower demand for university education than those living in large urban areas. Despite the lower parental human 
capital observed among most European groups, the higher educational attainment of their children relative to their parents reflects the modes of incorporation that speak to a more favourable reception of the host society. This inherently alleviates the obstacles that the second generation may encounter in their pursuit of higher education.

Despite the difference in racial composition and university education between Canada and the US, the pattern of racial/ethnic differences in university educational attainment is similar in the two countries. Given the geographic proximity and economic and social closeness of the two countries, it is possible that some mechanisms that produce these group differences operate in a similar way in both countries. In particular, the cultural value emphasizing the importance of education, family pressure and individual aspirations, community resources, and pursuit of higher education as a coping strategy for anticipated discrimination, are likely the major reasons underlying the success of East Asians (Chinese, Japanese, and Koreans) and South Asians in both Canada and the US. The disadvantage of Black youth is related to the possibility that the general inferior socioeconomic status of the parental generation has a longlasting and transnational impact on Black youth's educational pathways.

Our results confirm that parental education and social and ethnic capital form only part of the story, in that successful schooling adaptation or stagnation in educational achievement is, to a large extent, based on the settlement experiences of the parental generation and the unique characteristics of the ethnic communities in which these children are raised. High levels of human capital among the first generation will not necessarily translate to successful integration for their offspring if their parents do not receive a higher rate of return to their own schooling, if they encounter discrimination, or if they are concentrated in low-paying occupations. On the other hand, immigrant groups who are favourably received by the host society regardless of their levels of human or social capital can be assured that their children will be on their path towards successful adaptation to the extent that they are able to exceed their parents' levels of education. Immigrants who arrive with very high levels of human and financial capital ensure a place at the upper economic stratum. Those armed with this advantage, coupled with strong cultural orientations towards achievement, can rely on the strength of their ethnic community resources, further contributing to the successful pursuit of higher education. As Canada's population continues to receive people from nontraditional sources, it is likely that the unique settlement experiences of various groups will have implications for the enduring segmented patterns of educational outcomes, and that stratification in the educational system will further be compounded by differences in race and ethnicity. 


\section{REFERENCES}

Anisef, Paul, Paul Axelrod, Etta Baichman Anisef, Carl James, and Anthony Turrittin. 2000. Opportunity and Uncertainty: Life Course Experiences of the Class of '73. Toronto: University of Toronto Press.

Aydemir, Abdudrrahman and Mikal Skuterud. 2005. Explaining the deteriorating entry earnings of Canada's immigrant cohorts, 1966-2000. Canadian Journal of Economics 38(2):641-672.

Balakrishnan, T.R. and Zheng Wu. 1992. Home ownership patterns and ethnicity in selected Canadian cities. Canadian Journal of Sociology 17(3):389403.

Bollman, Ray. 1999. Human Capital and Rural Development: What are the Linkages? Statistics Canada, Agriculture Division Working Paper \#39. Ottawa: Statistics Canada Catalogue number 21-601-MIE1999039.

Borjas, George. 1995. Ethnicity, neighborhoods, and human capital externalities. American Economic Review 85(3):365-390. 1994. Long run convergence of ethnic skill differential: The children and grandchildren of the Great Migration. Industrial and Labor Relations Review 47(4):553-573. 1992. Ethnic capital and intergenerational mobility. Quarterly Journal of Economics 107(1):123-150.

Boyd, Monica. 2002. Educational attainments of immigrant offspring: Success or segmented assimilation? International Migration Review 36(4):10371060 .

Boyd, Monica and Elizabeth Grieco. 1998. Triumphant transitions: Socioeconomic achievements of the second generation in Canada. International Migration Review 32(3):853-876.

Caplan, Nathan, Marcella H. Choy, and John Whitmore. 1991. Children of the Boat People: A Study of Educational Success. Ann Arbor, MI: University of Michigan Press.

Chow, Henry. 2000. The determinants of academic performance: Hong Kong immigrant students in Canadian schools. Canadian Ethnic Studies 32(3):105-110.

Codjoe, Henry. 2001. Fighting a "public enemy" of black academic achievement: The persistence of racism and the schooling experiences of black students in Canada. Race, Ethnicity and Education 4(4):343-375

Coleman, James. 1990. Foundations of Social Theory. Cambridge, MA: Belknap Press of Harvard University Press

Corak, Miles. 2001. Are the Kids all Right? Intergenerational Mobility and Child Well-being in Canada. Analytical Studies Branch Research Paper Series 2001171e. Ottawa: Statistics Canada.

Davies, Scott and Neil Guppy. 1998. Race and Canadian education. Pp. 131-155 in Vic Satzewich, ed., Racism and Social Inequality in Canada: Con- 
cepts, Controversies and Strategies of Resistance. Toronto: Thompson Educational Publishing Inc.

Dinovitzer, Ronit, John Hagan, and Patricia Parker. 2003. Choice and circumstance: Social capital and planful competence in the attainments of immigrant youth. Canadian Journal of Sociology 28(4):463-488.

Duncan, Greg J. 1994. Families and neighbors as sources of disadvantage in the schooling decisions of white and black adolescents. American Journal of Education 103(1):20-53.

Frenette, Marc. 2004. Access to college and university: Does distance to school matter? Canadian Public Policy 30(4):427-443.

Fuligni, Andrew, Vivian Tseng, and May Lam. 1999. Attitudes toward family obligations among American adolescents from Asian, Latin American, and European backgrounds. Child Development 70(4):1030-1044.

Glick, Jennifer and Michael White. 2003. The academic trajectories of immigrant youths: Analysis within and across Cohorts. Demography 40(4):759-783.

Guppy, Neil and Scott Davies. 1998. Education in Canada: Recent Trends and Future Challenges. Ottawa: Statistics Canada and the Minister of Industry.

Halli, Shiva and Vedanand. 2007. The problem of second-generation decline: Perspectives on integration in Canada. Journal of International Migration and Integration 8(3):277-287.

Heckman, James. 2000. Policies to foster human capital. Research in Economics 54(1):3-56.

Hirschman, Charles. 2001. The educational enrollment of immigrant youth: A test of the segmented assimilation hypothesis. Demography 38(3):317336.

Hou, Feng and T.K. Balakrishnan. 1996. The integration of visible minorities in contemporary Canadian society. Canadian Journal of Sociology 21(3):307-326.

Hum, Derek and Wayne Simpson. 2000. Not all visible minorities face labour market discrimination. Policy Options 21(December):45-48.

Kalbach, Madeline and Warren Kalbach. 1995. The importance of ethnic connectedness for Canada's post-war immigrants. Canadian Ethnic Studies 27(2):16-33.

Kao, Grace and Jennifer S. Thompson. 2003. Racial and ethnic stratification in educational achievement and attainment. Annual Review of Sociology 29: 417-42.

Kelly, Philip. 2006. Filipinos in Canada: Economic Dimensions of Immigration and Settlement. CERIS Working Paper. Toronto: Joint Centre of Excellence for Research on Immigration and Settlement. 
Krahn, H. and Alison Taylor. 2005. Resilient teenagers: Explaining the high educational aspirations of visible minority youth in Canada. Journal of International Migration and Integration 6(3-4):405-434.

Li, Jun. 2001. Expectations of Chinese immigrant parents for their children's education: The interplay of Chinese tradition and the Canadian context. Canadian Journal of Education 26(4):477-494.

Li, Peter. 2003. Destination Canada: Immigration Debates and Issues. Toronto: Oxford University Press.

Miller, L. Scott. 1995. An American Imperative: Accelerating Minority Educational Advancement. New Haven, CT: Yale University Press.

Mouw, T. and Y. Xie. 1999. Bilingualism and the academic achievement of first and second generation Asian Americans: Accommodation with or without assimilation? American Sociological Review 64(2):232-252.

Oaxaca, Ronald and Michael Ransom. 1994. On discrimination and the decomposition of wage differentials. Journal of Econometrics 61(1):5-21.

Ogbu, Ju. 1991. Immigrant and involuntary minorities in comparative perspective. Pp. 3-33 in M.A. Gibson, ed., Minority Status and Schooling. New York: Garland.

Ornstein, Michael. 2000. Ethno-Racial Inequality in Toronto: Analysis of the 1996 Census. http://www.utoronto.ca/diversity/pdf/ornstein_fullreport. pdf. Accessed August 15, 2008.

Portes, Alejandro, Patricia Fernandez-Kelly and William Haller. 2005. Segmented assimilation on the ground: The new second generation in early adulthood. Ethnic and Racial Studies 28(6):1000-1040.

Portes, Alejandro and Dag MacLeod. 1996. Educational progress of the children of immigrants: The roles of class, ethnicity, and school context. Sociology of Education 69(4):255-275.

1999. Educating the second generation: Determinants of academic achievement among children of immigrants in the United States. Journal of Ethnic and Migration Studies 25(July):373-396.

Portes, Alejandro and Ruben Rumbaut. 2001. Legacies: The Story of the Immigrant Second Generation. Berkeley, CA: University of California Press and Russell Sage Foundation.

Portes, Alejandro and Min Zhou. 1993. The new second generation: Segmented assimilation and its variants. Annals of the American Academy of Political and Social Sciences 530(November):74-96.

Renaud, V. and R. Costa. 1999. 1996 Census of Population: Certification Report, Population Group. Ottawa: Housing, Family and Social Statistics Division, Statistics Canada.

Rice, P. 1999. The impact of local labour markets on investment in further education: Evidence from the England and Wales youth cohort studies. Population Economics 12(2):287-312. 
Richmond, Anthony. 1990. The income of Caribbean immigrants. Pp. 363-380 in Shiva Halli, Frank Trovato, and Leo Driedger, eds., Ethnic Demography. Ottawa: Carleton University Press.

Rumbaut, Ruben. 2005. Turning points in the transition to adulthood: Determinants of educational attainment, incarceration, and early childbearing among the children of immigrants. Ethnic and Racial Studies 28(6):1041-86.

Rumberger, Russell W. and Katherine A. Larson. 1998. Toward explaining differences in educational achievement among Mexican Americans language-minority students. Sociology of Education 71(1):68-92.

Shaienks, D. and T. Gluszynski. 2007. Participation in Postsecondary Education: Graduates, Continuers and Drop Outs, Results from YITS, Cycle 4, Research Paper, No. 81-595-MIE. Ottawa: Culture, Tourism and Centre for Education Statistics, Statistics Canada.

Simmons, Alan. 1998. Racism and immigration policy. Pp. 87-114 in Vic Satzewich, ed., Racism and Social Inequality in Canada: Concepts, Controversies and Strategies of Resistance. Toronto: Thompson Educational Publishing Inc.

Simmons, Alan and Dwaine Plaza. 1998. Breaking through the glass ceiling: The pursuit of university training among African-Caribbean migrants and their children in Toronto. Canadian Ethnic Studies 30(3):99-120.

Smith, Andrea, Barry H. Schneider, and Martin D. Ruck. 2005. Thinking about makin' it: Black Canadian students' beliefs regarding education and academic achievement. Journal of Youth and Adolescence 34(4):347-359.

Statistics Canada. 2005. Population Projections of Visible Minority Groups, Canada, Provinces and Regions, 2001-2017. Ottawa: Statistics Canada, catalogue no. 91-541-XIE.

2003. Ethnic Diversity Survey: Portrait of a Multicultural Society, Ottawa: Statistics Canada: Catalogue no. 89-593-XIE.

Stelcner, Morton. 2000. Earnings differentials among ethnic groups in Canada: A review of the research. Review of Social Economy 58(3):295-317.

Sue, Stanley and Sumie Okazaki. 1990. Asian-American educational achievements: A phenomenon in search of an explanation. American Psychologist 45(8):913-920.

Teixeira, Carlos. 2007. Residential experiences and the culture of suburbanization: A case study of Portuguese homebuyers in Mississauga. Housing Studies 22(4):495-521.

Troper, Harold. 2000 History of Immigration to Toronto since the Second World War: From Toronto "the Good" to Toronto "the World in a City." Toronto: University of Toronto: CERIS Working Paper No. 12.

Valenzuela, Angela and Sanford Dornbusch. 1994. Familism and social capital in the academic achievement of Mexican origin and Anglo adolescents. Social Science Quarterly 75(1):18-36. 
Warren, John R. 1996. Educational inequality among White and Mexican-origin adolescents in the American Southwest: 1990. Sociology of Education 69(2):142-58.

Wilkinson, Lori. 2002. Factors influencing the academic success of refugee youth in Canada. Journal of Youth Studies 5(2):173-193.

Worswick, Christopher. 2004. Adaptation and inequality: Children of immigrants in Canadian schools. Canadian Journal of Economics 37(1):53-77.

Xie, Yu and Kimberly Goyette. 2003. Social mobility and the educational choices of Asian Americans. Social Science Research 32(3):467-498.

Yau, Maria, Maisy Cheng, and Suzanne Ziegler. 1993. The 1991 Every Student Survey: Part III. Program Level and Student Achievement No. 205. Toronto: Toronto Board of Education.

Zhou, Min. 1997. Segmented assimilation: Issues, controversies and recent research on the new second generation. International Migration Review 31(4):975-1008.

Zhou, Min and Susan Kim. 2006. Community forces, social capital and educational achievement: The case of supplementary education in the Chinese and Korean immigrant communities. Harvard Educational Review 76(1): $1-29$.

Zhou, Min and Yang Sao. 2005. The multifaceted American experiences of the children of Asian immigrants: Lessons for segmented assimilation. Ethnic and Racial Studies 28(6):1119-1152.

Teresa Abada is Assistant Professor at the University of Western Ontario, Department of Sociology. Her research interests focus on selected aspects of the experiences of children and youth including the integration experiences of the children of immigrants; health; family change. Currently, she is investigating the social, cultural, and human capital factors that shape the children of immigrants' economic and social integration.

Feng Hou is a senior researcher with Business and Labour Market Analysis Division, Statistics Canada. His current research focuses on immigrant integration, socioeconomic outcomes of visible minority groups, and neighbourhood dynamics. He holds a PhD in social demography from the University of Western Ontario. He is the author/co-author of over 30 journal articles and book chapters.

Bali Ram is Senior Research Advisor, Demography Division, Statistics Canada and Adjunct Research Professor, Department of Sociology and Anthropology, Carleton University. He obtained his Ph.D. in Sociology from the Ohio State University in 1975. He was President of Research Committee on Sociology of Population, International Sociological Association during 2003-2006 and President of the Federation of Canadian Demographers during 1999-2002. He has published about 40 articles in various sub-fields of demography. 